\title{
In-office drainage of a frontoethmoidal mucocele with non-axial proptosis: an alternative to operating-room drainage
}

\author{
Przeprowadzony ambulatoryjnie drenaż torbieli zastoinowej błony śluzowej (mucocele) \\ w przedniej czę́si zatoki sitowej z towarzyszącym nieosiowym wytrzeszczem: \\ alternatywa dla drenażu w warunkach sali operacyjnej
}

\author{
1 Department of Otorhinolaryngology - Head and Neck Surgery, Hospital Ampang, Selangor, Malaysia \\ ${ }^{2}$ Faculty of Medicine and Health Sciences, Islamic Science University of Malaysia, Kuala Lumpur, Malaysia \\ ${ }^{3}$ Department of Otorhinolaryngology - Head and Neck Surgery, Universiti Kebangsaan Malaysia Medical Centre, Kuala Lumpur, Malaysia \\ Correspondence: Dr Reuben Abraham Thomas, Department of Otorhinolaryngology, Head and Neck Surgery, Hospital Ampang, Jalan Mewah Utara, Pandan Indah, 68000 Ampang, Selangor, Malaysia, \\ tel.: +6017 7721985, e-mail: reubencrm@gmail.com
}

Abstract Mucocele of the paranasal sinus is a cystic lesion with accumulation of mucus within the sinus walls, which is capable of expansion. The frontal sinus is most commonly involved, whereas ethmoidal, sphenoid, and maxillary mucoceles are rare. The floor of the frontal sinus is shared with the superior orbital wall, which explains orbital displacement in enlarging frontal mucoceles. This article presents a case of a spontaneous right frontoethmoidal mucocele with non-axial proptosis in a 26-year-old male patient who was referred by an ophthalmologist to our ENT (ear, nose, throat) clinic for a biopsy to rule out a sinonasal malignancy. An intranasal endoscopic approach was done to obtain a tissue biopsy in a clinic setting, which turned out to be a both diagnostic and therapeutic procedure with complete resolution of symptoms.

Keywords: frontoethmoidal mucocele, in-office drainage, proptosis

Streszczenie Torbiel zastoinowa błony śluzowej (mucocele) zatok przynosowych jest zmianą o charakterze torbielowatym, wywołaną gromadzeniem się śluzu w obrębie ścian zatok. Mucocele ma tendencję do rozszerzania się i najczęściej umiejscawia się w okolicy zatok czołowych - torbiele zatok sitowych, klinowych i szczękowych stanowią rzadkość. Dno zatok czołowych jest wspólne z górną ścianą oczodołu, co wyjaśnia przemieszczenie oczodołu wywoływane przez rozrastające się mucocele w obrębie zatoki czołowej. W poniższej pracy przedstawiono przypadek torbieli zastoinowej błony śluzowej umiejscowionej w przedniej części prawej zatoki sitowej, która pojawiła się samoistnie u 26-letniego mężczyzny wraz z towarzyszącym nieosiowym wytrzeszczem. Pacjent został skierowany przez okulistę do naszej poradni laryngologicznej w celu wykonania biopsji, aby wykluczyć nowotwór złośliwy zatok przynosowych. Aby pobrać materiał biopsyjny tkanki w warunkach ambulatoryjnych, wykonano endoskopię wewnątrznosową, która okazała się zabiegiem zarówno diagnostycznym, jak i terapeutycznym, skutkując całkowitym ustąpieniem objawów.

Słowa kluczowe: torbiel zastoinowa błony śluzowej (mucocele) przedniej części zatoki sitowej, drenaż w warunkach ambulatoryjnych, wytrzeszcz oka 


\section{INTRODUCTION}

$\mathrm{M}$ ucoceles are slow expanding mucus-containing benign cystic lesions lined with pseudostratified respiratory epithelial lining, which usually develop after chronic obstruction of the ostia of paranasal sinuses ${ }^{(1)}$. Mucoceles are most common in adults, and usually originate from a sinus obstruction, which may be spontaneous due to its anatomical variation or secondary to factors such as inflammation, tumour, trauma, or past paranasal sinus surgery - possibly because of the complexity of this region's anatomy and drainage ${ }^{(2)}$. They may expand and exert pressure on the bony boundaries, invading nearby vital structures such as the skull base and orbit, and causing intracranial and/or orbital complications. Mucoceles primarily occur in the frontal sinuses $(60 \% \text { to } 65 \%)^{(3)}$. This is due to the complex drainage and narrow structures of the frontal recess and frontal sinus. Surgery is the only curative treatment, and the endoscopic marsupialisation technique can solve most cases ${ }^{(4)}$. This procedure is usually done under general anaesthesia. However, in patients without anxiety, septated mucoceles, or neo-osteogenesis, in-office drainage with only topical anaesthesia has been reported ${ }^{(5)}$. Despite studies demonstrating cost savings associated with performing rhinologic procedures in the office rather than in the operating room, there are very few published reports regarding in-office drainage of sinus mucoceles.

\section{CASE REPORT}

A 26-year-old man presented with right eye protrusion of a 2-month duration, associated with diplopia. He had no eye pain or reduced vision. He denied any rhinitis symptoms, fever, facial pain or headache, previous surgical procedures, or trauma. He also negated any purulent or foulsmelling nasal discharge. On physical examination, there was fullness felt over the right medial epicanthus, with restricted extraocular muscle (EOM) movement over the superior rectus (Fig. 1). There was diplopia elicited on superior gaze. Otherwise, all EOM movements and visual acuity

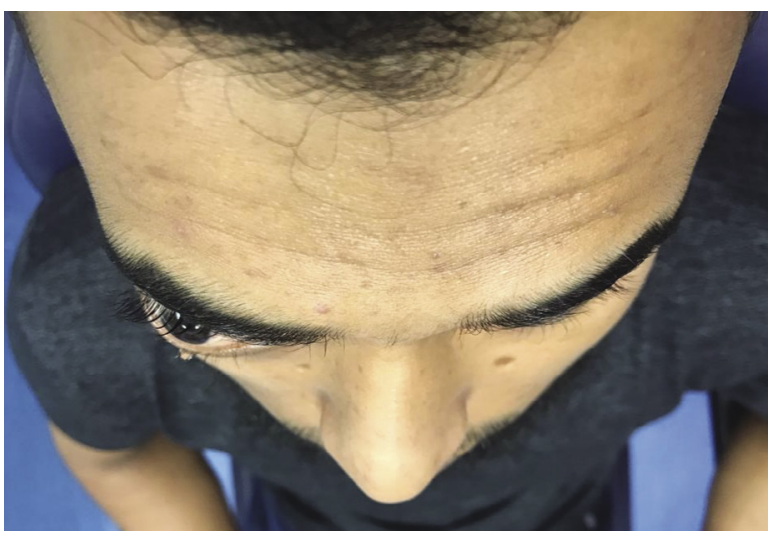

Fig. 1. Bird's eye view of the patient showing non-axial proptosis of the right eye were normal. Exophthalmometry revealed a measurement of $25 \mathrm{~mm}$ on the right and $18 \mathrm{~mm}$ on the left, and an intraocular pressure of $13 \mathrm{~mm} \mathrm{Hg}$. Rigid nasal endoscopic examination showed a fluctuant swelling protruding from the right lateral nasal wall adjacent to the axilla of the middle turbinate.

Contrast-enhanced computed tomography (CECT) of the brain and orbit revealed a heterogeneously enhancing soft tissue mass $(4.2 \times 2.9 \times 3.3 \mathrm{~cm})$ with its epicenter in the right anterior nasal cavity, which extends into and occupies the entire right frontal sinus, maxillary sinus and anterior ethmoidal sinus, through the widened maxillary ostium and infundibulum obliterating the right osteomeatal complex, and parts of the middle and superior nasal meati (Fig. 2). The findings were associated with remodeling and resorption of the medial maxillary wall and lamina papyracea, causing lateralisation and proptosis of the right globe. It abuts and laterally displaces the superior oblique, superior and medial recti muscles. In the absence of any cystic or calcified component reported on the CECT, a differential of sinonasal malignancy needed to be excluded, and which is why the patient was referred to our ear, nose and throat (ENT) department.

An attempt at punch biopsy under local anesthesia was done over the swelling under endoscopic guidance; however, a gush of approximately 10 cc's thick mucoid fluid was drained from the cavity, which gave an almost immediate reduction of the patient's proptosis. With the aid of an angled endoscope via the opened cavity, no obstruction of the frontal recess and ostia was seen, and the mucosal edges around the drained site were widened to ensure patency (Fig. 3).

Histopathological results of the mucocele wall showed acute on chronic inflammatory benign respiratory mucosa, with fragments of mature bone tissue. Post-operatively, the patient was followed up for 7 months both at the ophthalmology and ENT clinics, with the resolution of diplopia, ophthalmoplegia, a significant reduction in exophthalmometry readings, and without recurrence (Fig. 4).

\section{DISCUSSION}

Mucoceles were first described by Langenbeck (1820) under the name of hydatides, and it was Rollet (1909) who

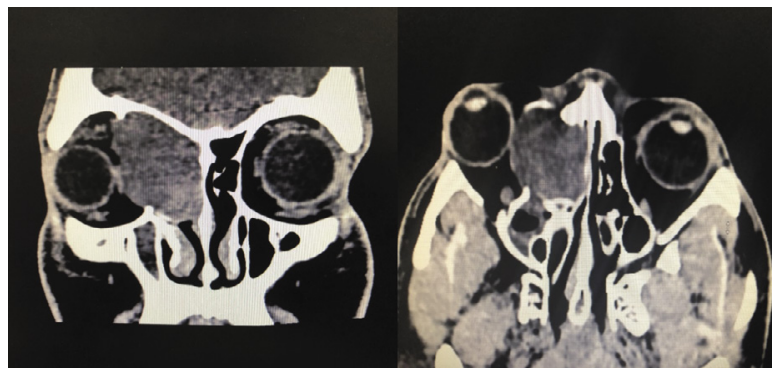

Fig. 2. High-resolution computed tomography scan showing the mucocele causing a mass effect with orbital displacement 


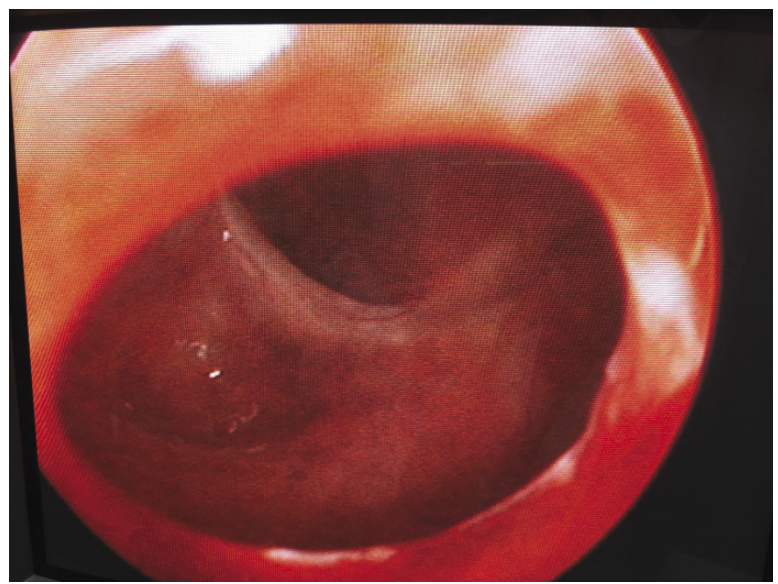

Fig. 3. Endoscopic view of the patent mucocele cavity and frontal sinus post drainage

suggested the name mucocele. Mucoceles have been described as collections of mucous enclosed in a sac of lining sinus epithelium within an air sinus resulting from an obstruction to the outlet of the cavity which may cause an expansion of the sinus by resorption of the bony walls ${ }^{(6)}$. Since a mucocele expands in the direction of least resistance, frontal mucoceles tend to erode the thin bone of the superior orbital wall, thus extending into the orbit and displacing the globe inferiorly, causing non-axial proptosis ${ }^{(7)}$. This abnormality, together with its effect on ocular motility, can result in diplopia and restricted ocular movements, causing most patients to first seek an ophthalmologist's advice, as it happened in our case ${ }^{(7)}$.

There are several causes for the obstruction including anatomical variation, infection, and inflammatory conditions such as acute or chronic rhinosinusitis, allergic rhinitis (allergic or infectious), trauma, previous surgery, benign tumours (osteoma, bone fibrous dysplasia) and rarely malignant tumours (primary or metastatic) ${ }^{(8)}$. Allergic Aspergillus sinusitis may be related to the formation of a mucocele, and these patients may also have a history of asthma, nasal polyps, and chronic sinusitis ${ }^{(9)}$. No demonstrable cause can be determined in about a third of all patients ${ }^{(10)}$. Insignificant past medical history from our patient's presentation could also explain an idiopathic cause. In some reported cases, there is histological evidence of an increased number of secretory cells in the epithelium of the lesions that produce increased amounts of mucus that may contribute to mucocele formation ${ }^{(10)}$.

CT of paranasal sinuses is considered by many authors as the preferred method for evaluating a mucocele because it can visualise bone involvement and extensions of the lesion in detail, yielding the necessary information for surgical planning. Mucoceles are generally isodense to the brain parenchyma, with attenuation values ranging from 10 to $40 \mathrm{HU}$, reflecting the hydration and protein concentration of the mucoid contents. The older the lesion is, the higher its attenuation value ${ }^{(10)}$. Occasionally, non-enhancing hyperdense areas within the mucocele, frequently in a stippled pattern, looking
These are believed to represent inspissated, dehydrated mucocele content which mimics a tumour, just like in our patient's case, a differential diagnosis of a sinonasal malignancy needed to be considered. Although magnetic resonance imaging (MRI) is less sensitive than CT in visualising bone erosions, it has the advantage of multiplanar imaging, delineating the extension of lesions better than CT. In addition, it is considered the method of choice in differentiating a mucocele from a tumour or for excluding an underlying tumour causing ostium obstruction based on MRI signal intensity characteristics ${ }^{(11)}$. Generally, signal intensity in T1WI is determined by protein concentration and mucus viscosity, while signal intensity in T2WI is determined by the water content of the lesions. Usually, mucoceles have high T2 signal and low to high T1 signal, reflecting an increased water concentration and different proteinaceous sinus contents ${ }^{(11)}$. We could not proceed further for MRI due to our patient's financial constraints and had to rely on the CT findings.

Surgical drainage is the only curative treatment for sinus mucoceles $^{(2)}$. Endoscopic marsupialization has proven to be an effective therapeutic modality, and its use should be encouraged. Some patients with frontal mucocele will require combined access, especially when the lesion is located more laterally or associated with abundant neo-osteogenesis, which can hinder opening of the frontal recess ${ }^{(12)}$. An endoscopic, minimally invasive approach allows the sinus to regain its normal function with restored mucociliary clearance, and facilitates continued endoscopic examination of the operated sinus cavity ${ }^{(13)}$. Through advances in instrumentation, cameras, and computerised image guidance, an endoscopic approach to sinus mucoceles has largely replaced open procedures. Furthermore, when compared to an open approach, studies utilising an endoscopic approach have demonstrated a similar recurrence rate ( $2.3 \%$ vs. $4.2 \%)$, and an even lower complication rate $(20.8 \% \text { vs. } 1.0 \%)^{(14)}$.

There is only one retrospective review of a surgeon's experience with in-office endoscopic drainage of sinus mucoceles between 2006 and 2014, which was published by Barrow and DelGaudio ${ }^{(5)}$. Neither orbital nor skull base erosions are contraindications to in-office drainage of mucoceles, as the approach should be in an area away from the orbit and skull base, thereby maximising drainage and minimising the risk of complications. The presence of septations and

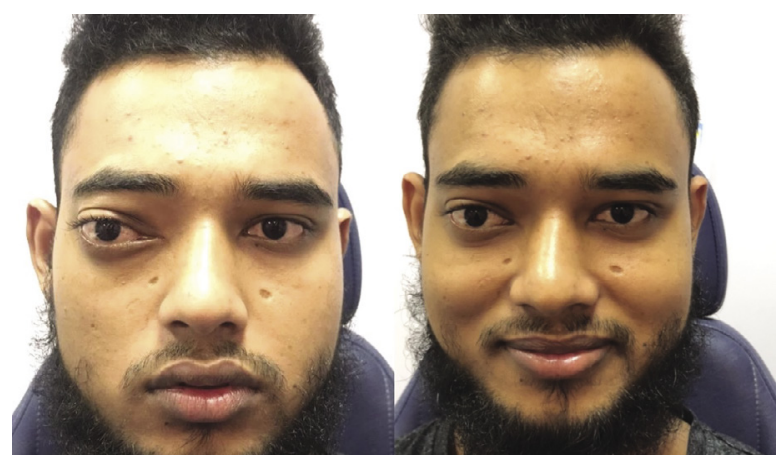

Fig. 4. Pre-drainage (left) and post-drainage (right) images 
neo-osteogenesis can reduce the chance of complete drainage, thus representing relative contraindications ${ }^{(5)}$. Septations that are located superiorly or laterally in the frontal recess or fontal sinus make complete drainage more difficult in the office setting. Neo-osteogenesis can be problematic when it is dense and located at the point of planned entry into the mucocele. If it is located away from the site of entry or is not dense, the patient may still be a good candidate for office drainage. Due to the financial constraints faced by our patient and in hindsight of our flow of treatment, office-based mucocele drainage provides significant cost savings, while eliminating risks associated with general anaesthesia and ensuring a significantly shorter perioperative time for surgeons and patients. Furthermore, there is no lost time from work for the patient except for the day of the procedure, which results in less social impact due to fewer lost workdays.

\section{CONCLUSIONS}

In-office frontal sinus mucocele drainage appears to be a feasible technique and a potential alternative to conventional endoscopic procedures in the operating room. In carefully selected patients (without the presence of septations and neo-osteogenesis), the technique can obviate the need for general anaesthesia and the operating room, and potentially reduce surgical costs.

\section{Conflict of interest}

The authors do not report any financial or personal connections with other persons or organisations which might negatively affect the content of this publication and/or claim authorship rights to this publication.

\section{Consent}

A written consent has been obtained from the patient for publication of his picture for use in this case report as stipulated by local regulations of law.

\section{References}

1. Tan CSH, Yong VKY, Yip LW et al.: An unusual presentation of a giant frontal sinus mucocele manifesting with a subcutaneous forehead mass. Ann Acad Med Singap 2005; 34: 397-398.

2. Devars du Mayne M, Moya-Plana A, Malinvaud D et al.: Sinus mucocele: natural history and long-term recurrence rate. Eur Ann Otorhinolaryngol Head Neck Dis 2012; 129: 125-130.

3. Marambaia O, Gomes AM, Marambaia PP et al.: Tratamento endoscópico das mucoceles frontoetmoidais. Rev Bras Otorrinolaringol 2008; 74 (Suppl 1).

4. Kennedy DW, Josephson JS, Zinreich SJ et al.: Endoscopic sinus surgery for mucoceles: a viable alternative. Laryngoscope 1989; 99: 885-895.

5. Barrow EM, DelGaudio JM: In-office drainage of sinus mucoceles: an alternative to operating-room drainage. Laryngoscope 2015; 125: 1043-1047.

6. Alberti PWRM, Marshall HF, Black JIM: Fronto-ethmoidal mucocoele as a cause of unilateral proptosis. Br J Ophthalmol 1968; 52: 833-838.

7. Tasman W, Jaeger EA: Duane's Clinical Ophthalmology. Vol. 2, JB Lippincott Co, New York 1994: 3-7.

8. Chiarini L, Nocini PF, Bedogni A et al.: Intracranial spread of a giant frontal mucocele: case report. Br J Oral Maxillofac Surg 2000; 38: 637-640.

9. Katzenstein AL, Sale SR, Greenberger PA: Allergic Aspergillus sinusitis: a newly recognized form of sinusitis. J Allergy Clin Immunol 1983; 72: 89-93.

10. Lloyd G, Lund VJ, Savy L et al.: Optimum imaging for mucoceles. J Laryngol Otol 2000; 114: 233-236.

11. Van Tassel P, Lee YY, Jing BS et al.: Mucoceles of the paranasal sinuses: MR imaging with CT correlation. AJR Am J Roentgenol 1989; 153: 407-412.

12. Plantier DB, Neto DB, Pinna FR et al.: Mucocele: clinical characteristics and outcomes in 46 operated patients. Int Arch Otorhinolaryngol 2019; 23: 88-91.

13. Scangas GA, Gudis DA, Kennedy DW: The natural history and clinical characteristics of paranasal sinus mucoceles: a clinical review. Int Forum Allergy Rhinol 2013; 3: 712-717.

14. Courson AM, Stankiewicz JA, Lal D: Contemporary management of frontal sinus mucoceles: a meta-analysis. Laryngoscope 2014; 124: 378-386. 